\title{
HYDROCHEMICAL PARAMETERS IN A PORTION OF THE PARAÍBA DO SUL RIVER HYDROGRAPHIC BASIN, SÃO JOSÉ DOS CAMPOS CITY, SÃO PAULO STATE, BRAZIL
}

\author{
ISABELLA G. LEE \& DANIEL M. BONOTTO \\ Departamento de Geologia, Instituto de Geociências e Ciências Exatas - UNESP, Rio Claro, Brazil
}

\begin{abstract}
This paper describes a hydrochemical study held in a portion of the Paraíba do Sul river hydrographic basin that is located in São José dos Campos city at eastern of São Paulo State, Brazil. It comprises Lambari river, a tributary of the Paraíba do Sul river, which crosses the installations of the Henrique Lage Oil Refinery (REVAP). Here is reported the hydrochemical parameters of the Lambari river waters that drain the refinery in order to identify possible impacts on the water resources due to the presence of the refinery. All samples analyzed (32) exhibited a similar hydrochemical pattern, except sample IL-02, which presented different values for most of the parameters analyzed. The samples exhibited $\mathrm{pH}$ values between 6.16 and 7.41 and Eh values between +260 and $+324 \mathrm{mV}$, except for one outlier value for sample IL-02 $(-170 \mathrm{mV})$, which is reduced, according to Eh-pH diagram. The following mean values were found for the parameters analyzed in this study, disregarding the outlier sample IL-02: temperature $=26.4^{\circ} \mathrm{C}$; Electrical Conductivity $(\mathrm{EC})=108.03 \mu \mathrm{S} / \mathrm{cm}$; alkalinity $=32 \mathrm{mg} / \mathrm{L}$; turbidity $=6.8 \mathrm{FTU}$; Total Dissolved Solids $($ TDS $)=62.9 \mathrm{mg} / \mathrm{L} ; \mathrm{Ca}^{2+}=2.6 \mathrm{mg} / \mathrm{L} ; \mathrm{Mg}^{2+}=1.04 \mathrm{mg} / \mathrm{L}$; $\mathrm{Na}^{+}=13.6 \mathrm{mg} / \mathrm{L} ; \mathrm{K}^{+}=2.8 \mathrm{mg} / \mathrm{L} ; \mathrm{Cl}^{-}=8.2 \mathrm{mg} / \mathrm{L} ; \mathrm{NO}_{3}{ }^{-}=1.2 \mathrm{mg} / \mathrm{L} ; \mathrm{SO}_{4}{ }^{2-}=1.5 \mathrm{mg} / \mathrm{L}$. Based on the mean hydrochemical composition, the waters were classified as sodium bicarbonate. An analysis was performed to determine surfactants and tannin-lignin in the sample IL-02, resulting in values of 0.302 $\mathrm{mg} / \mathrm{L}$ and $2.6 \mathrm{mg} / \mathrm{L}$, respectively. It is believed that this sample has an excessive contribution of domestic effluents, since it has high levels of surfactants and its collection point is located close to a sewage pipe.

Keywords: surface waters, hydrochemical parameters, oil refinery.
\end{abstract}

\section{INTRODUCTION}

Surface waters are very important for the society maintenance because they represent one of the main sources of water supply in the planet. Thus, hydrochemical studies focusing the surface waters quality are necessary for proper planning and management of the water resources in a region. Watercourses in metropolitan regions are impacted by anthropogenic activities taking place in numerous drainages, which are related to both constant population growth and industrial practices, thus, requiring greater exploitation of the water resources and causing the water degradation due to the inputs of domestic and industrial effluents. This paper describes a hydrochemical study held in a portion of the Paraíba do Sul river hydrographic basin. The study area is located in the Paraíba valley region that is an important economic axis between São Paulo and Rio de Janeiro in Brazil, which possesses a great demand for water resources because comprises large and medium-sized cities, such as Jacareí, Taubaté, Aparecida do Norte and São José dos Campos at São Paulo State.

More specifically, this study was held at São José dos Campos city, located in the east of São Paulo State, focusing the Henrique Lage Refinery (REVAP) area, one of the most remarkable oil refineries from Petrobras in Brazil (Fig. 1). The site is located in a portion of the Paraíba do Sul river hydrographic basin, comprising Lambari river, a tributary of the Paraíba do Sul river, which crosses the installations of the refinery. São José dos Campos city is home of important companies and research centers in the country. In addition, it is an 
important technopole of warlike and metallurgical materials, as well the headquarters of the largest aerospace complex in Latin America.

Because of the increasing use of water resources and the difficulty of maintaining and recovering them in cases of contamination, the understanding of the physical, physicochemical and chemical characteristics of the waters is essential for their proper management. Thus, due to the proximity of the oil refinery to the study area, the hydrochemical analysis of surface water in the region are essential for their appropriate use. This research aims to describe some hydrochemical parameters of the Lambari river waters that are close to the refinery in order to identify possible changes in their quality associated to the presence of the refinery.

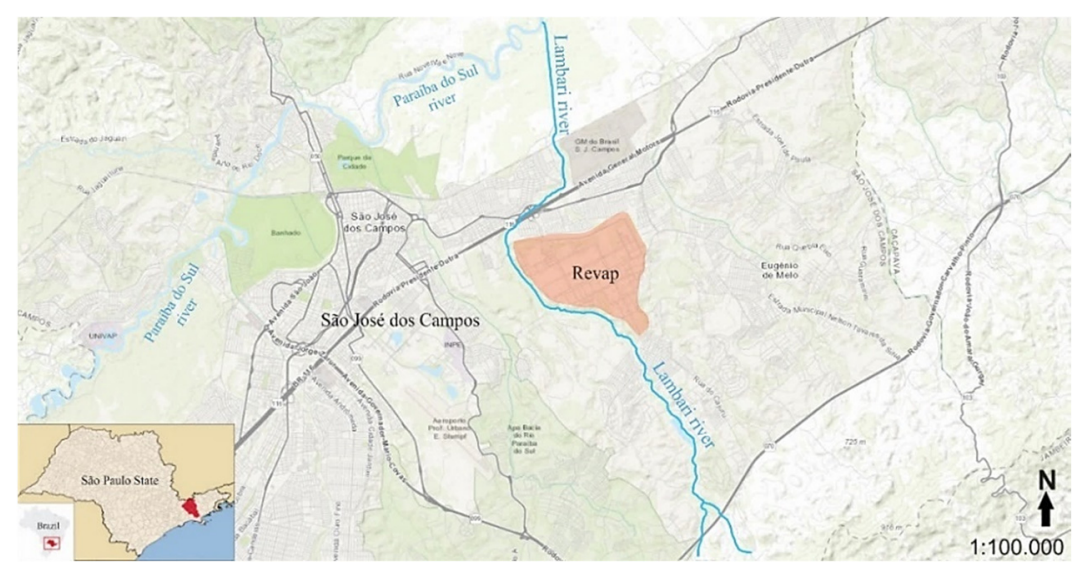

Figure 1: Location of the study area.

\section{STUDY AREA}

The study area is inserted in the Paraíba do Sul river hydrographic basin which covers an area of approximately $57,000 \mathrm{~km}^{2}$, and extends to three states in the southeastern region of Brazil: São Paulo, Minas Gerais and Rio de Janeiro. In the state of São Paulo, the Paraíba do Sul river hydrographic basin covers several cities, including Cruzeiro, Guaratinguetá, Jacareí, Lorena, São José dos Campos, Taubaté and Aparecida do Norte. The main water body in this hydrographic basin is the Paraíba do Sul river, which is formed by the confluence of the Paraitinga and Paraibuna rivers. The main tributaries are the Jaguari, Paraibuna, Pomba and Muriaé rivers, on the left bank, and the Piraí, Piabanha and Dois Rios rivers, on the right bank. It flows into the Atlantic Ocean, discharging at São João da Barra, Rio de Janeiro State [1].

The Paraíba do Sul river basin is divided into four sub-basins: Low Paraíba do Sul basin, Muriaé/Pomba basin, Paraibuna basin, and High Paraíba do Sul Basin. The Lambari river, focused in this study, is a tributary of Paraíba do Sul river and is located in the High Paraíba do Sul sub-basin, more accurately at São José dos Campos city. It flows from southeast to northwest of São José dos Campos city, crossing the Henrique Lage Refinery (REVAP) (Fig. 1). The major access to the site is by Presidente Dutra highway (BR-116) that links São Paulo to Rio de Janeiro cities.

The study area is inserted in the geological context of Taubaté basin, which is a rift-type basin characterized by continental and syntectonic sedimentation associated to fluvial and lacustrine environments [2]-[4]. Geomorphologically, it is situated at Paraíba do Sul river valley that is a lowered surface embedded in Precambrian rocks limited by Mantiqueira mountain range at northwestern and Mar mountain range at southeastern [5]. The sedimentation 
comprised a phase syntectonic to the rift (deposition of sediments from Taubate Group that include the formations Resende, Tremembé and São Paulo) and a phase after the dystrophic tectonics (deposition of Pindamonhangaba Formation and alluvial/colluvial sediments) [4].

The climate is warm and temperate at São José dos Campos region, with a significant rainfall along the year. It is classified as Cfa according to the Köppen and Geiger classification [6] as exhibits an average temperature of $19.4^{\circ} \mathrm{C}$ and mean annual rainfall of $1269 \mathrm{~mm}$. The remaining vegetation consists on the Atlantic Forest that dominates the slopes of Mantiqueira mountain range and banks of Paraíba do Sul river.

\section{MATERIALS AND METHODS}

This study started with fieldwork for the samples collection and involved in situ tests and laboratorial analysis. The collection of water samples from the Lambari river was conducted in late October and early November 2019 at 30 previously defined points that were regularly distributed throughout the perimeter of interest, with an interval of approximately $400 \mathrm{~m}$ between them (Fig. 2). In addition, two samples were also collected at Paraíba do Sul river in points situated upstream and downstream of the Lambari river discharge. The water sampling was performed according to location, access and functionality. The coordinates of all sampling points were recorded during the fieldwork, as well as their collection time.

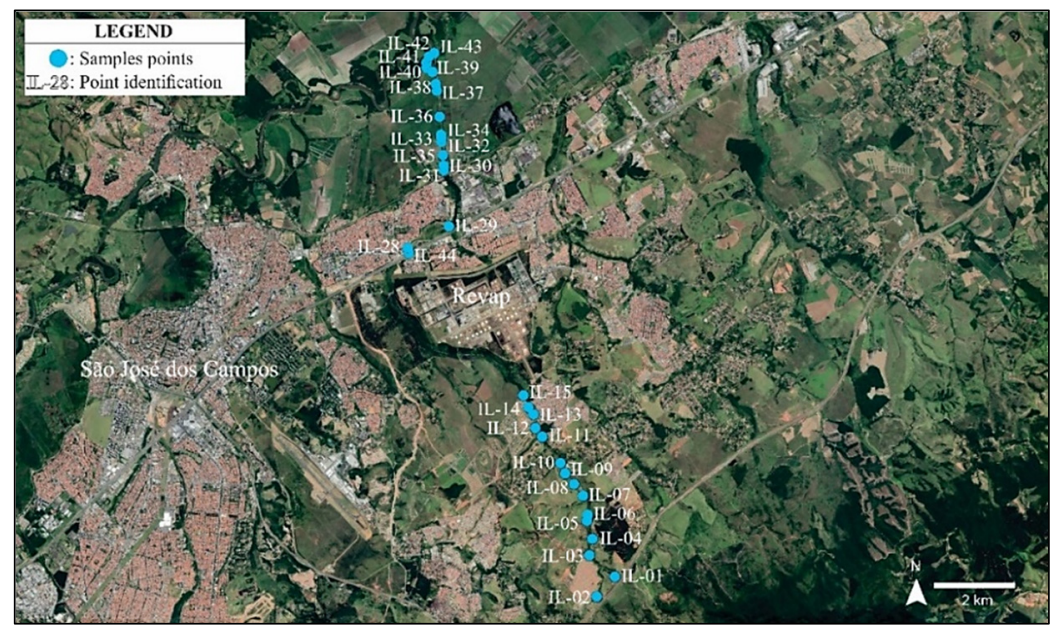

Figure 2: Location of the 32 samples collection points.

Polyethylene terephthalate containers duly identified and numbered were used for sampling, which were previously washed and rinsed at the collection time with the water sampled, in order to avoid contamination. It was initially recovered about $5 \mathrm{~L}$ of water from each point and the temperature readings were done with a precision reading thermometer, as quickly as possible, in order to avoid changes in its value. For the analysis of the physicochemical parameters, the samples were stored in 2L-volume polyethylene flasks. After checking the hydrogen potential $(\mathrm{pH})$, oxidation-reduction potential $(\mathrm{Eh})$, electrical conductivity (EC), alkalinity and turbidity, the samples were carefully handled and taken to LABIDRO-Isotopes and Hydrochemistry Laboratory, IGCE-UNESP - Rio Claro Campus, for hydrochemical analysis of sodium $\left(\mathrm{Na}^{+}\right)$, potassium $\left(\mathrm{K}^{+}\right)$, calcium $\left(\mathrm{Ca}^{2+}\right)$, magnesium $\left(\mathrm{Mg}^{2+}\right)$, chloride $\left(\mathrm{Cl}^{-}\right)$, sulfate $\left(\mathrm{SO}_{4}{ }^{2-}\right)$, nitrate $\left(\mathrm{NO}_{3}{ }^{-}\right)$, surfactants, and tannin-lignin. 
The $\mathrm{pH}$ was measured with a portable Digimed digital equipment, which was coupled to a combined glass electrode model KASVI. The determination of Eh was performed with the same device, however, it was coupled to a combined Digimed platinum electrode, model 12L12069, which was calibrated with a Zobell solution, according to the procedure described by Bonotto [7].

The electrical conductivity (EC) was measured with one Analion digital equipment, model C-702. Alkalinity was measured by titration with $0.02 \mathrm{~N}$ sulfuric acid by the Hach method 8221 - Buret Titration whose readings are in the concentration range between 0 and $500 \pm$ $0.2 \mathrm{mg} / \mathrm{L}$ [8]. Turbidity was determined by the Hach method 8237 - Absorptometric, using the Hach spectrophotometer, model DR/2000 [8].

The determination of sodium and potassium was made by the flame atomic emission spectrometry method, through the Benfer flame photometer, model BFC-300. The calcium and magnesium data were obtained by the Hach method 8030 - Calmagite Colorimetric, chloride by the Hach method 8113 - Mercuric Thiocyanate, and sulfate by the Hach method 8051 SulfaVer 4, all them using the Hach DR/2000 spectrophotometer [8]. Nitrate was measured by the Hach method 10020 - Chromotropic Acid in a Hach DR/2700 spectrophotometer [8].

The summation of the concentration of the main cations $\left(\mathrm{Na}^{+}, \mathrm{K}^{+}, \mathrm{Ca}^{2+}, \mathrm{Mg}^{2+}\right)$ and anions $\left(\mathrm{Cl}^{-}, \mathrm{SO}_{4}{ }^{2-}, \mathrm{NO}_{3}^{-}, \mathrm{HCO}_{3}^{-}\right)$in the analyzed waters allowed determine the Total Dissolved Solids concentration (TDS 1). In addition, in order to check such results, it was estimated another TDS value (TDS 2) of the samples through the theoretical relationship between TDS and $\mathrm{EC}$ in natural waters as proposed by Hem [9]:

$$
\operatorname{TDS} 2(\text { in } \mathrm{mg} / \mathrm{L})=\mathrm{EC}\left(\text { in } \mu \mathrm{S} / \mathrm{cm} \text { at } 25^{\circ} \mathrm{C}\right) \times \mathrm{A} \text {, }
$$

where $\mathrm{A}$ is a factor ranging from 0.5 to 1.0 . However, usually $\mathrm{A}$ is between 0.55 and 0.75 , except for waters exhibiting unusual composition. In this study, it was adopted $A=0.65$ that corresponds to the average of the most common A values.

Surfactants and tannin-lignin analysis were also performed in order to obtain an explanation for the fact that one sample presented outliers values of Eh, EC, TDS, alkalinity, turbidity, calcium, sodium, potassium, chloride, nitrate and sulfate. Surfactants data often indicate the presence of domestic effluents in the waters such as cleaning products (detergents) and cosmetic products (shampoos), whilst tannin-lignin data identify possible effects of plant decomposition in the waters. For comparison purposes, the analysis was made for the outlier sample (IL-02) and another sample (IL-39) that exhibited the second highest measured EC value. The surfactants were measured using the Hach method 8028 - Crystal Violet [8], whereas the tannin-lignin data were obtained using the Hach method 8193 Tyrosine [8]. In both cases, the Hach DR/2000 spectrophotometer model was used for the readings. In order to characterize the hydrochemical facies of the waters, a free software (Qualigraf, v. 1.17) was used, which was developed by FUNCEME - Ceará Meteorology and Water Foundation.

\section{RESULTS AND DISCUSSION}

Table 1 shows the results obtained in this study. The temperature measured in situ varied little, with values ranging from $24.6^{\circ} \mathrm{C}$ to $32.8^{\circ} \mathrm{C}$. The $\mathrm{pH}$ values indicated that the analyzed waters are basically neutral, with little variation in $\mathrm{pH}$, ranging from 6.16 to 7.41. The Eh values are between +260 and $+324 \mathrm{mV}$, except for the outlier value of the sample IL-02 $(-170 \mathrm{mV})$. Based on the $\mathrm{pH}$ and Eh data, the waters of the Lambari river can be classified as slightly oxidizing, except the sample IL-02 that is reduced as shown in the Eh-pH diagram (Fig. 3) that characterizes the type of environment where the water is flowing. 
Table 1: Minimum (Min.), maximum (Max.) and mean values obtained for the parameters analyzed in the 32 water samples.

\begin{tabular}{|l|c|c|c|c|}
\hline Parameter & Unit & Min. & Max. & Mean \\
\hline Temperature & ${ }^{\circ} \mathrm{C}$ & 24.6 & 32.8 & 26.4 \\
\hline Eh & $\mathrm{mV}$ & -170 & 324 & 299 \\
\hline $\mathrm{pH}$ & - & 6.16 & 7.41 & 6.89 \\
\hline $\mathrm{EC}$ & $\mu \mathrm{S} / \mathrm{cm}$ & 72.6 & 560 & 108.03 \\
\hline TDS 1 & $\mathrm{mg} / \mathrm{L}$ & 42.27 & 284.45 & 62.93 \\
\hline TDS 2 & $\mathrm{mg} / \mathrm{L}$ & 47.19 & 364 & 70.22 \\
\hline$\Delta$ TDS ${ }^{1}$ & $\mathrm{mg} / \mathrm{L}$ & 0.19 & 79.55 & 9.89 \\
\hline Turbidity & $\mathrm{FTU}$ & 1 & 120 & 6.84 \\
\hline Sodium & $\mathrm{mg} / \mathrm{L}$ & 7.36 & 52.21 & 13.57 \\
\hline Potassium & $\mathrm{mg} / \mathrm{L}$ & 0.59 & 10.32 & 2.85 \\
\hline Calcium & $\mathrm{mg} / \mathrm{L}$ & 0.03 & 11.40 & 2.6 \\
\hline Magnesium & $\mathrm{mg} / \mathrm{L}$ & 0.56 & 1.66 & 1.04 \\
\hline Alkalinity & $\mathrm{mg} / \mathrm{L}$ & 22 & 108 & 32 \\
\hline Chloride & $\mathrm{mg} / \mathrm{L}$ & 1.90 & 48.80 & 8.16 \\
\hline Nitrate & $\mathrm{mg} / \mathrm{L}$ & 0.40 & 25.80 & 1.25 \\
\hline Sulfate & $\mathrm{mg} / \mathrm{L}$ & $<1$ & 27 & 1.52 \\
\hline
\end{tabular}

${ }^{1} \Delta$ TDS $=|\operatorname{TDS} 2-\operatorname{TDS} 1|$.

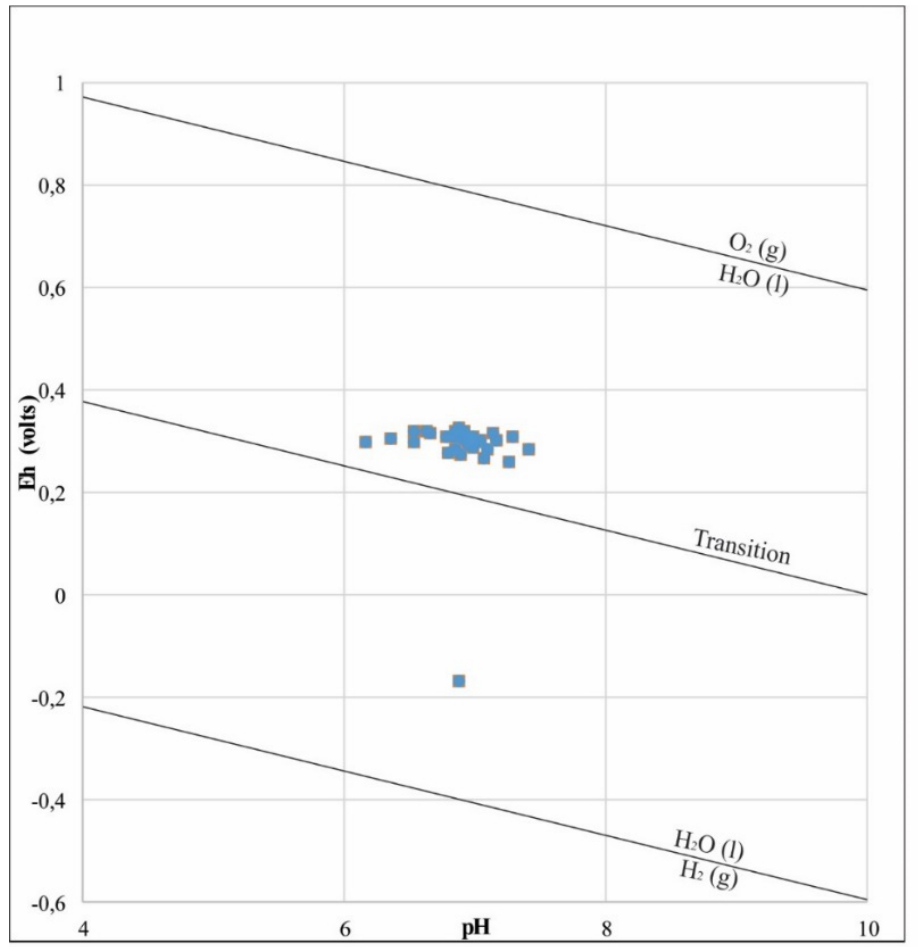

Figure 3: Data obtained for the waters analyzed in this study inserted in an Eh-pH diagram. 
The estimated TDS concentration (TDS 2) yielded satisfactory results, correlating significantly with TDS 1 and providing a difference relative to TDS 1 ( $\triangle$ TDS) that corresponded to a mean value of $9.9 \mathrm{mg} / \mathrm{L}$ (Table 1). Thus, the hydrochemical data have been discussed here considering the TDS 1 data.

The EC of the water samples ranged from 72.6 to $214 \mu \mathrm{S} / \mathrm{cm}$, the alkalinity between 22 and $64 \mathrm{mg} / \mathrm{L}$ of $\mathrm{CaCO} 3$, the turbidity between 1 and $42 \mathrm{FTU}$, and the TDS 1 from 42.27 to $115.1 \mathrm{mg} / \mathrm{L}$, except the sample IL-02, which showed values of $560 \mu \mathrm{S} / \mathrm{cm}$ (EC), $108 \mathrm{mg} / \mathrm{L}$ (alkalinity), 120 FTU (turbidity) and $284.45 \mathrm{mg} / \mathrm{L}$ (TDS 1).

The TDS 1-EC graph is shown in Fig. 4, showing a strong linear correlation (Pearson's coefficient $r=0.98)$. For turbidity, it was found that 10 samples $(31 \%)$ exhibited levels exceeding the maximum value allowed by the Brazilian Ministry of Health for drinking water corresponding to 5 FTU [10]. For TDS, all values are within the drinking requirements of the Brazilian Ministry of Health corresponding to $1000 \mathrm{mg} / \mathrm{L}$ [10].

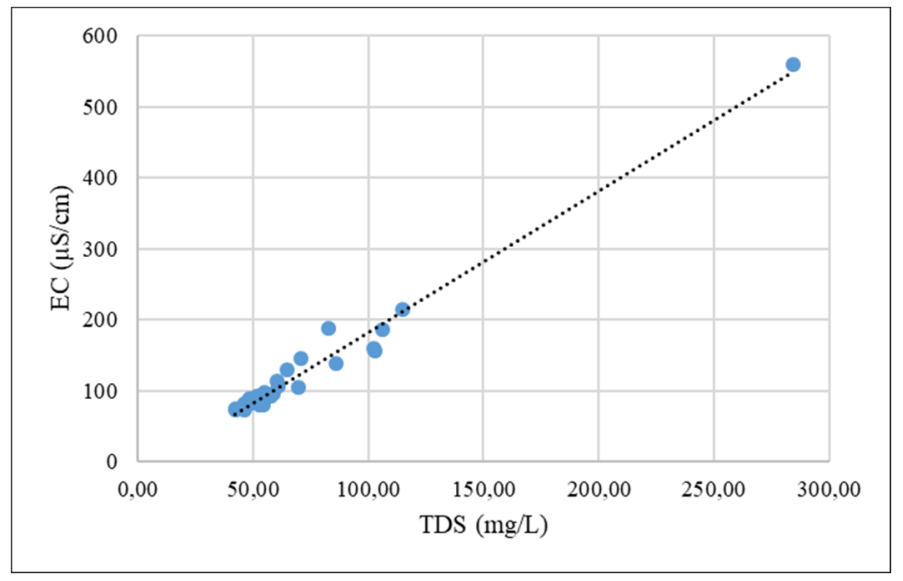

Figure 4: The TDS 1-EC graph obtained for all samples analyzed.

The graphs in Figs 5 and 6 show the relationships among alkalinity, EC and TDS 1. They indicate good data correlation, with Pearson coefficients of $r=0.89$ (Fig. 5) and $r=0.90$ (Fig. 6), characterizing high linear correlation among these parameters. The linear dependence between alkalinity and TDS 1 is consequence of the TDS 1-EC relationship. Bicarbonate (as indicated by alkalinity) often takes a major role in the chemical composition of the surface waters and it is a major constituent of the TDS 1 in the studied waters, offering a significant correlation with this parameter. It was also carried out a statistical analysis disregarding the outlier sample IL-02, but even in this case, the linear dependence still exists as the Pearson correlation coefficient corresponded to $r=0.66$ (alkalinity $v s$. EC) and $r=0.70$ (alkalinity $v s$. TDS 1).

The $\mathrm{pH}$, in turn, showed practically no linear dependence with EC and alkalinity (Pearson's correlation coefficient of -0.19 and -0.06 , respectively). The Eh variation in relation to the $\mathrm{pH}$ values for the study area was analyzed disregarding the outlier sample IL-02 (Fig. 7). The relationship between these two parameters is inversely proportional as often recognized in the literature. In our case, there is a slight trend of this inverse relationship as indicated by the Pearson correlation coefficient $r=-0.31$ (Fig. 7). 


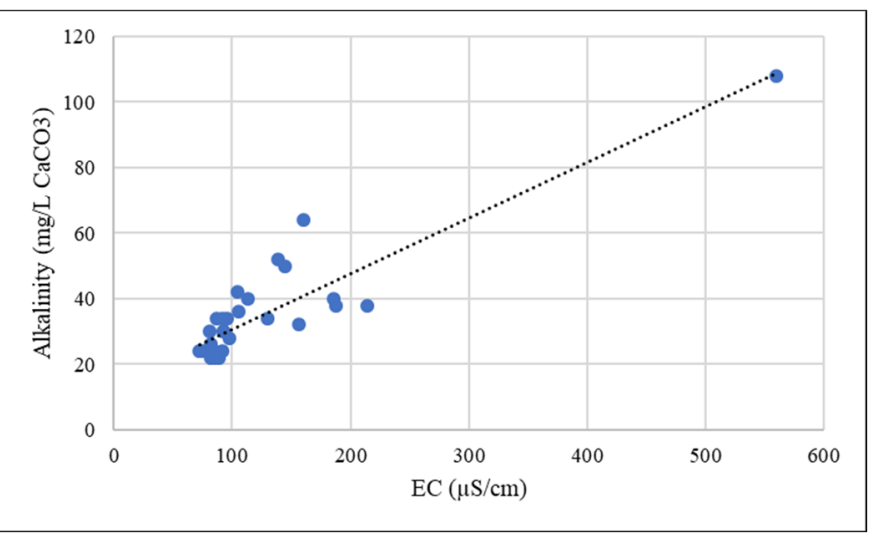

Figure 5: The alkalinity-EC graph obtained for all water samples analyzed.

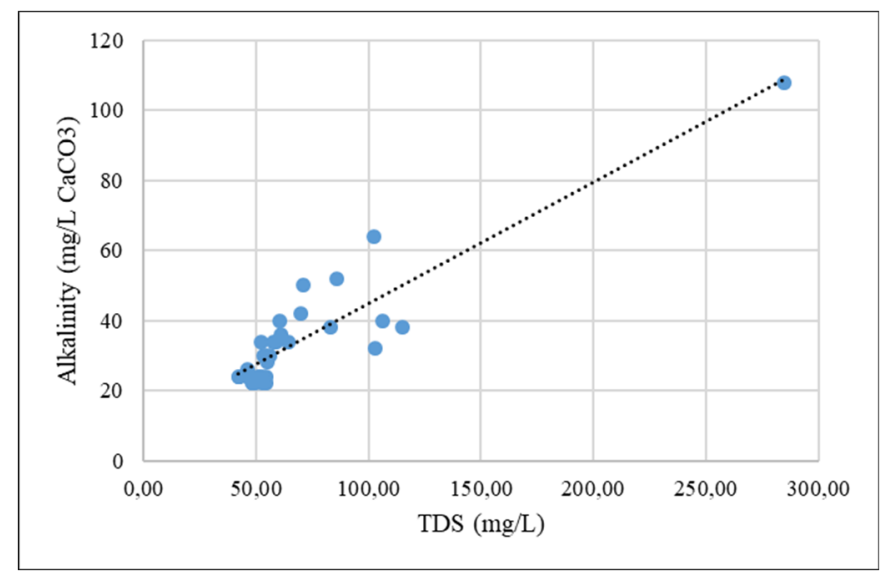

Figure 6: The alkalinity-TDS 1 graph obtained for all water samples analyzed.

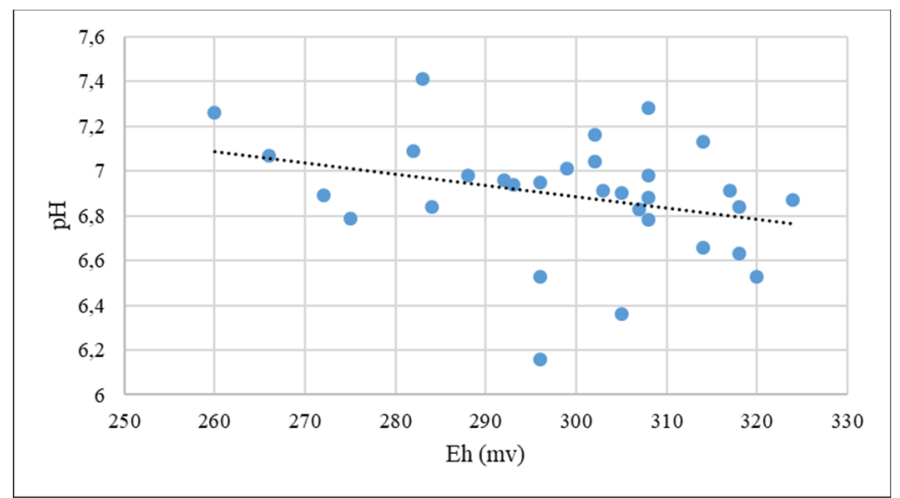

Figure 7: The $\mathrm{pH}-\mathrm{Eh}$ graph obtained disregarding the outlier sample IL-02. 
When analyzing the turbidity in relation to the TDS 1 concentration, a positive linear dependence was found (Pearson's correlation coefficient $r=0.90$ ) (Fig. 8) that is expected once the turbidity of a water body is directly associated with the levels of dissolved and suspended solids. These parameters were again submitted to the statistical analysis, disregarding the influence of the outlier sample and, in this case, the Pearson correlation corresponded to $r=0.43$, still showing a moderate linear dependence between these parameters.

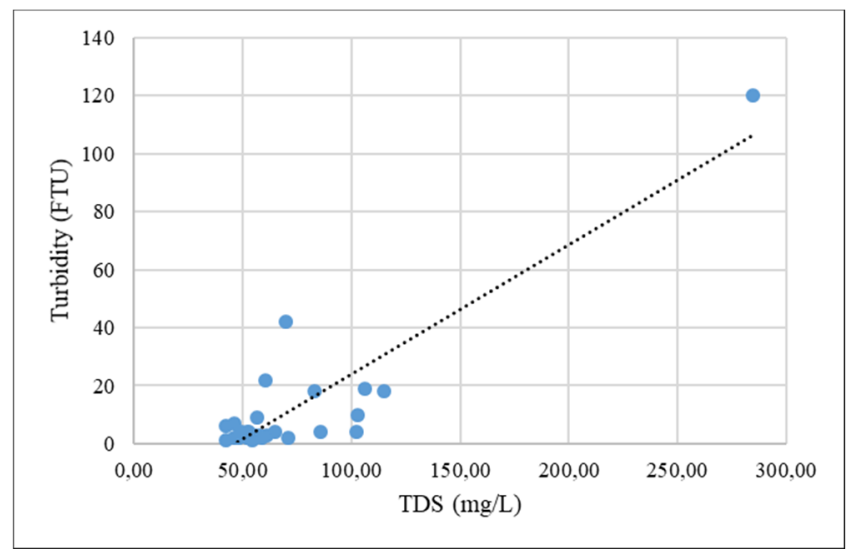

Figure 8: The turbidity-TDS 1 graph obtained for all water samples analyzed.

The calcium concentration was between 0.03 and $5.24 \mathrm{mg} / \mathrm{L}$, except for the sample IL-02 that corresponded to $11.4 \mathrm{mg} / \mathrm{L}$. For magnesium, the range was $0.56-1.66 \mathrm{mg} / \mathrm{L}$. The Brazilian Ministry of Health [10] allows up to $500 \mathrm{mg} / \mathrm{L}$ of Ca and $\mathrm{Mg}$ in drinking water that is a value well above of those found in the analyzed waters.

The maximum sodium concentration in drinking water allowed by the Brazilian Ministry of Health is $200 \mathrm{mg} / \mathrm{L}$ [10] that is above the values found here ( 7.36 to $27.83 \mathrm{mg} / \mathrm{L})$, even for sample IL-02 (52.21 mg/L). For potassium, the range was $0.59-6.99 \mathrm{mg} / \mathrm{L}$, except for sample IL-02 (10.32 mg/L).

The maximum nitrate concentration in drinking water allowed by the Brazilian Ministry of Health is $10 \mathrm{mg} / \mathrm{L} \mathrm{[10]}$ that is above the range $0.4-2.4 \mathrm{mg} / \mathrm{L}$ found here, except for sample IL-02 that surpassed it $(25.8 \mathrm{mg} / \mathrm{L})$, which may refer to contamination by septic tanks and sewage effluents.

The chloride levels were between 1.9 and $36.2 \mathrm{mg} / \mathrm{L}$, except for sample IL-02 (48.8 mg/L), but all these values are lower than the guideline reference value of $250 \mathrm{mg} / \mathrm{L}$ in drinking water, according to the Brazilian Ministry of Health [10].

The maximum sulfate concentration in drinking water allowed by the Brazilian Ministry of Health is $250 \mathrm{mg} / \mathrm{L}$ [10] that is above the values found here $(<1$ to $9 \mathrm{mg} / \mathrm{L})$, even for sample IL-02 (27 mg/L).

In addition to the alkalinity-EC relationship, sodium and chloride also correlated with the EC. For Na ${ }^{+}$, the Pearson's coefficient was $r=0.91$ (Fig. 9), whilst it was $r=0.84$ for $^{-}$ (Fig. 10). The correlation was significant even disregarding the outlier values of the sample IL-02 as it was found $\mathrm{r}=0.82$ for $\mathrm{Na}^{+}$(Fig. 11) and $\mathrm{r}=0.78$ for $\mathrm{Cl}^{-}$(Fig. 12).

The dominant hydrochemical composition of surface waters often reported in the literature is calcium-bicarbonated but in the study area it tends to be sodium-bicarbonated (Table 1). The strong significant correlations between EC and alkalinity (bicarbonate) 
(Fig. 5), as well between EC and sodium (Fig. 9) confirm such trend that is more accurately viewed in a Piper diagram [11] as shown in Fig. 13.

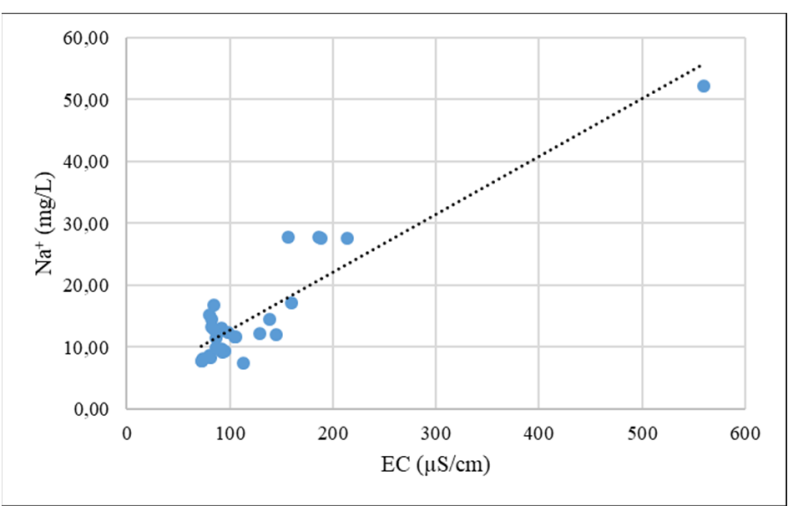

Figure 9: The Na-EC graph obtained from all samples analyzed.

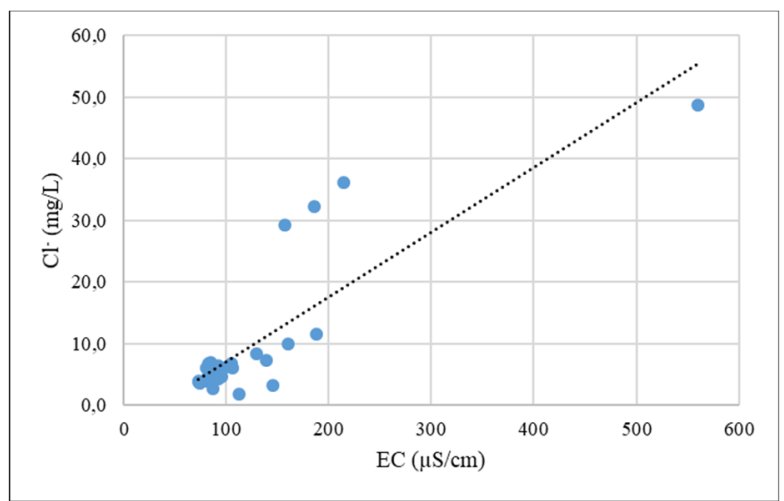

Figure 10: The Cl-EC graph obtained from all samples analyzed.

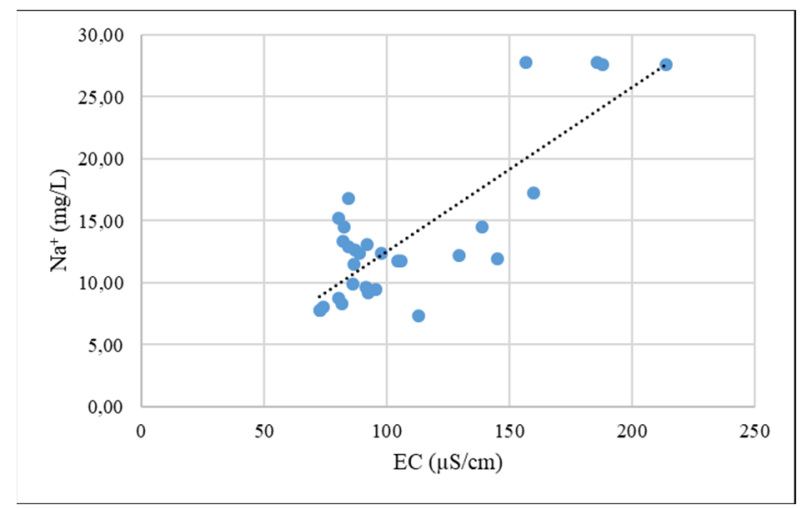

Figure 11: The Na-EC graph obtained disregarding the outlier sample IL-02. 


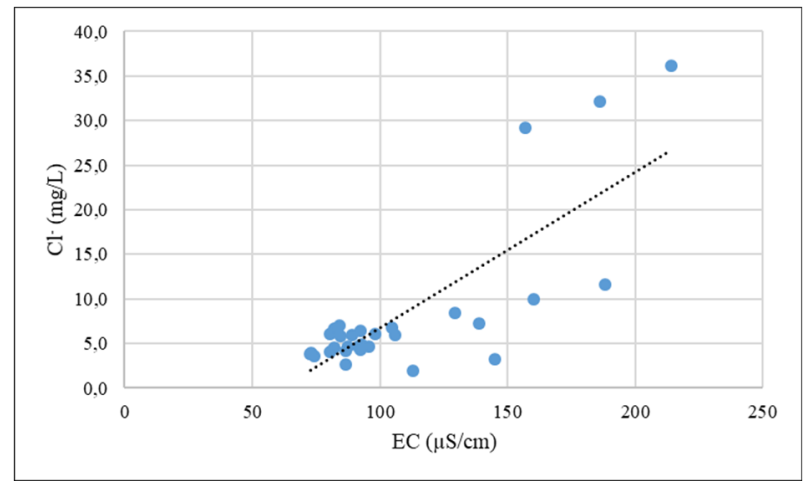

Figure 12: The Cl-EC graph obtained disregarding the outlier sample IL-02.

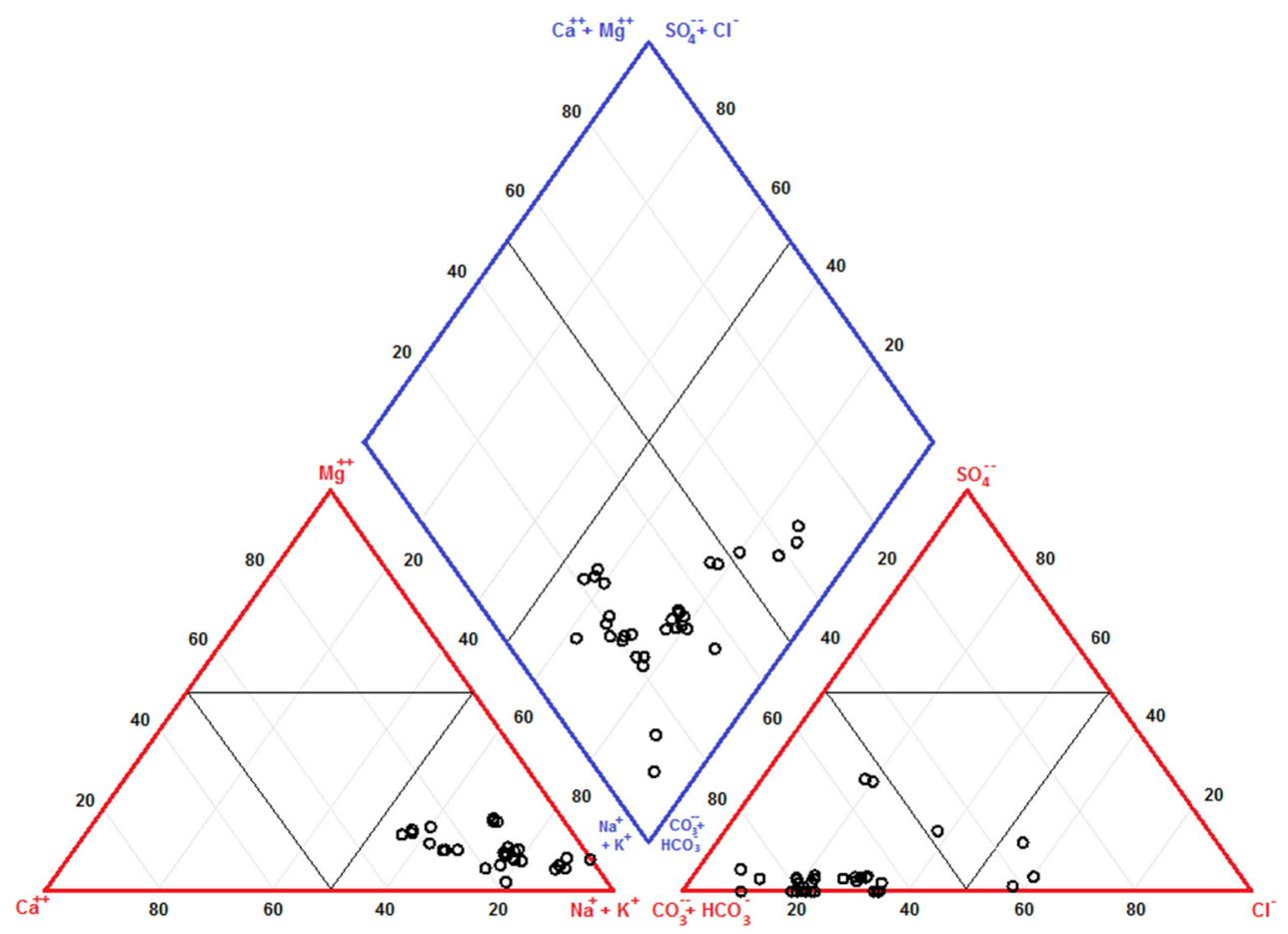

Figure 13: Chemical data of the analyzed samples (circles) plotted on a Piper diagram [11].

The insertion of the chemical data for the 32 samples analyzed in the Piper diagram [11] (Fig. 13) indicated that all them are classified as sodium-type waters, considering the dissolved cations. In terms of the dissolved anions, $88 \%$ are inserted in the field of the bicarbonate-type waters and $9 \%$ in the field of the chloride-type waters; the remaining 3\% corresponds to the outlier sample IL-02 that is inserted in the field of the mixed-type waters. 
The analysis to determine the values of surfactants for samples IL-02 and IL-39 indicated, respectively, $0.302 \mathrm{mg} / \mathrm{L}$ and $0.011 \mathrm{mg} / \mathrm{L}$, suggesting an accentuated presence of surfactants in the outlier sample IL-02. The high value found in this sample is close to the maximum allowed by the Brazilian Ministry of Health $(0.5 \mathrm{mg} / \mathrm{L})$ [10] and, along with its high concentration of chloride $(48.8 \mathrm{mg} / \mathrm{L})$ and nitrate $(25.8 \mathrm{mg} / \mathrm{L})$, suggests contamination by domestic effluents, such as cleaning products, cosmetics and sewage effluents. It is likely that the outliers of some of the physicochemical parameters analyzed in the sample IL-02 are related to these contaminants inputs. The analysis made to determine the tannin-lignin levels in the water samples IL-02 and IL-39 indicated values of $2.6 \mathrm{mg} / \mathrm{L}$ and $0.8 \mathrm{mg} / \mathrm{L}$, respectively. Thus, it is observed that the sample IL-02 has a greater influence in its hydrochemistry of plants decomposition, although not very significant.

\section{CONCLUSION}

The results of the present investigation focusing the waters of the Lambari river at São José dos Campos city, São Paulo State, Brazil, took into account parameters that allowed a helpful assessment of their quality, identifying possible environmental impacts occurring there. The physicochemical parameters analyzed in this paper confirmed that the Henrique Lage Oil Refinery (REVAP) did not influence their characteristics. However, additional studies are necessary to confirm such preliminary scenario, taking into account other parameters related to the water quality, for instance, minor and traces inorganic constituents, as well as organic compounds (BTEX - Benzene, Toluene, Ethyl-benzene and Xylenes). Sodium, chloride and alkalinity (bicarbonate) are the dominant constituents in the Lambari River waters, showing excellent linear correlation with the electrical conductivity (EC). The Piper diagram indicated that they are mostly sodium bicarbonate ( $88 \%$ of the samples), but also sodium chloride $(9 \%$ of the samples). One outlier sample (IL-02) was classified as sodium mixed, which presented discrepant values for most of the parameters analyzed, except for $\mathrm{pH}$ and $\mathrm{Mg}$. In that monitoring point, the composition could be related to an excessive contribution of domestic effluents as evidenced by its high surfactants level and also by sewage effluents as indicated by its higher concentration of chloride and nitrate. This is corroborated by the fact that the collection point of this sample is located close to a sewage pipe.

\section{REFERENCES}

[1] Amorim, D.D. \& Ferreira, M.E., Um estudo sobre a qualidade das águas do Rio Paraíba do Sul no Vale do Paraíba do Sul no período de 1978 a 1994. Presented at XIII Brazilian Symposium on Water Resources, Belo Horizonte, MG, 2000.

[2] Appi, C.J., Freitas, E.L. \& Castro, J.C., Faciologia e estratigrafia da Bacia de Taubaté. Technical report, CENPES/ Petrobras, 1986.

[3] Chang, H.K. et al., Geologia da Bacia de Taubaté. Presented at Southeastern Geology Symposium, Rio de Janeiro, RJ, p. 10, 1989.

[4] Riccomini, C., O rift continental do sudeste do Brasil. PhD thesis, University of São Paulo, São Paulo, 1989.

[5] Ross, J. \& Moroz, I., Mapa Geomorfológico do Estado de São Paulo. Journal of Geography Department, pp. 41-58, 2011.

[6] Climate Data Web Site, São José dos Campos Climate, Online. pt.climatedata.org/america-do-sul/brasil/sao-paulo/sao-jose-dos-campos-6151. Accessed on: 21 Jan. 2020.

[7] Bonotto, D.M., Comportamento hidrogeoquímico do ${ }^{222} \mathrm{Rn}$ e isótopos de urânio ${ }^{238} \mathrm{U}$ e ${ }^{234} \mathrm{U}$ sob condições controladas de laboratório e em sistemas naturais. Post-PhD thesis. São Paulo State University, Rio Claro, p. 223, 1996. 
[8] HACH, Water Analysis Handbook, 4th ed., Hach Company: Loveland, Colorado, 2000.

[9] Hem, J.D., Study and Interpretation of the Chemical Characteristics of Natural Water. U.S.G.S. Water Supply Paper, 1473, pp. 1-269, 1959.

[10] Ministério da Saúde Brasileiro, Portaria No 2914 de 12 de dezembro 2011. Procedimentos de controle e de vigilância da qualidade da água para consumo humano e seu padrão de potabilidade, p. 33, 2011.

[11] Piper, A., A graphic procedure in the geochemical interpretation of water-analyses. Transactions of the American Geophysical Union, 25(6), pp. 914-928, 1944. 